HIGHLIGHT

\title{
The role of $11 \beta$-hydroxysteroid dehydrogenase activity in the metabolic syndrome: lessons learned from the animal model
}

\author{
Jörg Dötsch and Wolfgang Rascher \\ Klinik für Kinder und Jugendliche, Loschgestr. 15, 91054 Erlangen, Friedrich-Alexander-Universität Erlangen-Nürnberg, Germany
}

(Correspondence should be addressed to Jörg Dötsch; Email: joergwdoetsch@yahoo.com)

The metabolic syndrome is a disease with ever-increasing prevalence and extensive cost to the health systems of the Western world. Until a decade ago, the etiology of this disease, dominated by obesity, diabetes mellitus type 2, hyperlipidemia, hypertension and subsequent morbidity such as arteriosclerosis, coronary heart disease and chronic renal failure, has by and large been attributed to overeating and a lack of physical exercise. In the last decade, however, exciting new findings have greatly increased our knowledge about factors contributing to the pathogenesis of obesity and its sequelae. One such finding is the association between low birth weight and obesity, diabetes mellitus and coronary heart disease first advocated by Barker leading to the so-called Barker hypothesis $(1,2)$. This initially criticized hypothesis has been widely accepted and confirmed for a number of different populations. However, the pathophysiological link between low birth weight and the metabolic syndrome still needs to be elucidated.

More conclusive data come from studies examining the genetic background of obesity and metabolic syndrome. A hallmark in this field was undoubtedly the discovery of the ob-gene product leptin in 1995 (3) and the subsequent identification of grossly obese children lacking leptin (4) or its receptor (5). Very soon after its discovery it became evident, however, that a deficiency of leptin did not account for the large majority of obese patients and, as expected, the treatment of obese subjects with recombinant leptin was rather disappointing (6). In the following years, a number of other monogenic causes of obesity have been identified in humans (7), all of which are characterized by loss-of-function mutations. Despite great efforts, however, only a number of individuals could be identified as being affected.

An interesting new animal study in the field of obesity research has now been designed by Jeffrey Flier's group in Boston. His group developed a strain of transgenic mice with visceral obesity and the metabolic syndrome by overexpressing $11 \beta$-hydroxysteroid dehydrogenase type 1 (11ß-HSD1) (8). This enzyme converts biologically inactive cortisone to cortisol which also binds avidly to the gluco- and mineralocorticoid receptors in humans (Fig. 1). 11ß-HSD1 is predomi- nately active in adipose tissue, in the liver and in the adrenal gland.

Until recently, the 11 $\beta$-HSD type 2 isoenzyme, in particular, was the major focus of research, since it plays a key role in the pathogenesis of one of the few monogenic causes of hypertension in the human, namely the apparent mineralocorticoid excess (9). Prior to the report by Masuzaki et al. (8), however, it had been suggested that an altered or shifted activity of both $11 \beta$-HSD isoenzymes might be involved in the pathogenesis of obesity and hypertension in human hypercortisolism (10). Convincing data on the pivotal role of 11ß-HSD1 isoenzyme overexpression in mice are now available. Masuzaki et al. (8) showed that their mice overexpressing 11ß-HSD1 not only had an increased enzyme activity but also exhibited two- to threefold higher local concentrations of corticosterone (the key glucocorticoid in rodents, equivalent to human cortisol) in mesenchymal adipose tissue. Most importantly, serum corticosterone concentrations in the transgenic mice were similar to those in their nontransgenic littermates, which is consistent with findings in most adipose tissue in humans who are lacking systemic hypercortisolism. The body weight of transgenic animals receiving a high fat diet exceeded that of nontransgenic littermates by $25-35 \%$. Interestingly, the increase in weight was mostly confined to mesenchymal fat tissue. The quantity of visceral fat has long been identified as the best predictor of morbidity emerging from obesity (4). The overexpression of $11 \beta-H S D 1$ did not lead to a higher number of adipose cells but induced a more than threefold adipocyte volume, an observation similarly found in obese humans. As expected, with the increase in fat mass, serum leptin concentrations rose in the $11 \beta-H S D 1$ transgenic mice. Nonetheless, the animals still remained hyperphagic as compared with their non-transgenic littermates implying, at least in these animals, that peripheral, paracrine mechanisms may well overcome the regulating effect of leptin that has proved to be so potent (3).

It is of utmost importance that 18-week-old transgenic mice developed clear biochemical features of the metabolic syndrome. Serum free fatty acid concentration and serum triglyceride concentrations rose 1.5- to 2.5-fold in comparison with the non-transgenic 


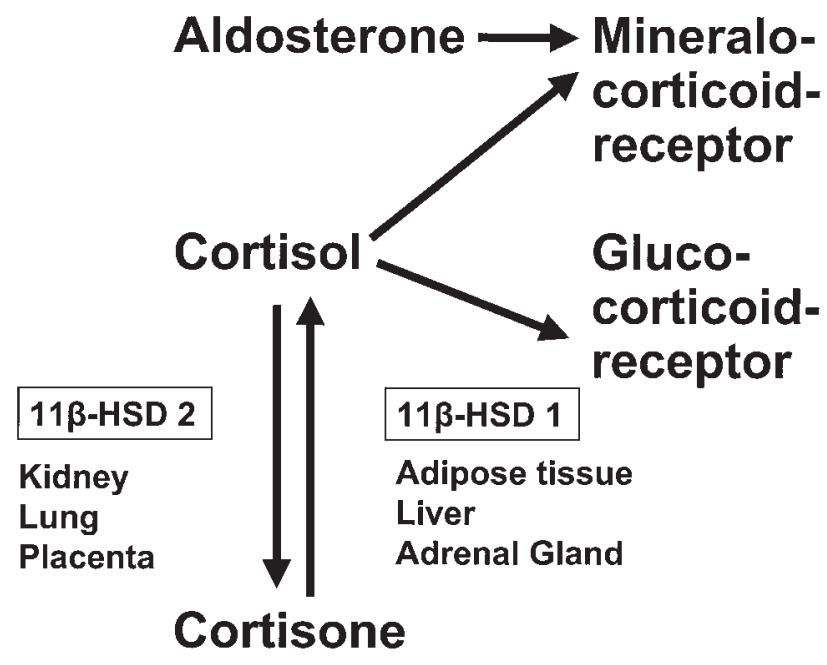

Figure $111 \beta-H S D$ isoenzymes: role in cortisol/cortisone conversion, receptor affinity and tissue distribution.

controls. Intraperitonal glucose tolerance and insulin tolerance tests revealed pathological profiles.

Certain restrictions, however, must be taken into account with regard to the transgenic model of visceral obesity described by Masuzaki et al. (8). As usual in the field of energy balance and body weight, rodent data cannot be transferred directly to the human, although hyperphagia in the transgenic mice, despite hyperleptinemia, much resembles conditions in the human. Secondly, the data depicted have been established only in male mice, completely neglecting female animals. Although visceral obesity is more prevalent in male humans, it is also present in women. It would be interesting to evaluate whether female animals behave like their male littermates in characterizing gender-specific effects. Another aspect is that blood pressure measurements are lacking in the report. Since hypertension is an essential feature of the metabolic syndrome and cortisol binds as avidly to the mineralocorticoid receptor as aldosterone (11) (Fig. 1), data on blood pressure regulation are needed to characterize the metabolic syndrome in the animals. Finally, the precise pathophysiological sequence of events following local hypercortisolism in transgenic animals remains to be shown. Despite descriptive evidence that glucocorticoid receptor $\alpha$ isoform and lipoprotein lipase mRNA expression in mesenteric adipose tissue may be involved, and expression of adipose genes that are known or suspected of influencing systemic metabolic pathways (adipocyte complement-related protein 30 (Acrp30)AdipoQ, Resistin, Angiotensinogen, uncoupling protein1 (UCP-1)) are altered in this animal model, functional and pharmacological studies may help to prove the relevance of these pathways and elucidate the exact mechanism.

Taken together, the transgenic 11ß-HSD1 mice allows for a link between human Cushing's syndrome in which hypercortisolism is mandatory and merely local (i.e. tissue-confined) hypercortisolism. Although cortisol concentrations are not elevated in the serum of obese humans (12), adipose tissue from obese humans has increased $11 \beta$-HSD1 activity (13). Thus, the enzyme may serve as a tissue-specific amplifier of glucocorticoid action (14). The concept of tissuespecific alteration of glucocorticoid activity is not new and is well known for the placental 11ß-HSD2 isoenzyme. By converting maternal cortisol to cortisone, the human placenta protects the fetus from cortisol excess which promotes intrauterine growth retardation and prenatal programming of hypertension $(15,16)$.

In summary, we learn from the exciting study on $11 \beta-H S D 1$ transgenic mice that tissue-specific glucocorticoid-dependent adipocyte pathways have a major impact on systemic metabolism and may provide a possible new target for the treatment of visceral obesity and the metabolic syndrome in humans.

\section{References}

1 Barker DJ, Osmond C, Golding J, Kuh D \& Wadsworth ME. Growth in utero, blood pressure in childhood and adult life, and mortality from cardiovascular disease. British Medical Journal 1989298 564-567.

2 Hales CN, Barker DJ, Clark PM, Cox LJ, Fall C, Osmond C et al. Fetal and infant growth and impaired glucose tolerance at age 64. British Medical Journal 1991303 1019-1022.

3 Halaas JL, Gajiwala KS, Maffei M, Cohen SL, Chait BT, Rabinowitz D et al. Weight-reducing effects of the plasma protein encoded by the obese gene. Science $1995269543-546$.

4 Montague CT, Farooqi IS, Whitehead JP, Soos MA, Rau H, Wareham NJ et al. Congenital leptin deficiency is associated with severe early-onset obesity in humans. Nature $1997 \mathbf{3 8 7} 903-908$.

5 Clement K, Vaisse C, Lahlou N, Cabrol S, Pelloux V, Cassuto D et al. A mutation in the human leptin receptor gene causes obesity and pituitary dysfunction. Nature $1998392398-401$.

6 Heymsfield SB, Greenberg AS, Fujioka K, Dixon RM, Kushner R, Hunt $\mathrm{T}$ et al. Recombinant leptin for weight loss in obese and lean adults: a randomized, controlled, dose-escalation trial. Journal of the American Medical Association 1999282 1568-1575.

7 Krude H, Biebermann H, Luck W, Horn R, Brabant G \& Gruters A. Severe early-onset obesity, adrenal insufficiency and red hair pigmentation caused by POMC mutations in humans. Nature Genetics 199819 155-157.

8 Masuzaki H, Paterson J, Shinyama H, Morton NM, Mullins JJ, Seckl JR et al. A transgenic model of visceral obesity and the metabolic syndrome. Science $20012942166-2170$.

9 Ulick S, Levine LS, Gunczler P, Zanconato G, Ramirez LC, Rauh W et al. A syndrome of apparent mineralocorticoid excess associated with defects in the peripheral metabolism of cortisol. Journal of Clinical Endocrinology and Metabolism 197949 757-764.

10 Dötsch J, Dörr HG, Stalla GK \& Sippell WG. Effect of glucocorticoid excess on the cortisol/cortisone ratio. Steroids $2001 \mathbf{6 6}$ $817-820$.

11 Stewart PM. Cortisol as a mineralocorticoid in human disease. Journal of Steroid Biochemistry and Molecular Biology 199969 403-408.

12 Wajchenberg BL. Subcutaneous and visceral adipose tissue: their relation to the metabolic syndrome. Endocrine Reviews 200021 697-738.

13 Rask E, Olsson T, Soderberg S, Andrew R, Livingstone DE, Johnson $\mathrm{O}$ et al. Tissue-specific dysregulation of cortisol metabolism in human obesity. Journal of Clinical Endocrinology and Metabolism $2001861418-1421$. 
14 Seckl JR \& Walker BR. Mini-review: 11beta-hydroxysteroid dehydrogenase type 1 - a tissue-specific amplifier of glucocorticoid action. Endocrinology $2001 \mathbf{1 4 2} 1371-1376$.

15 Schoof E, Girstl M, Frobenius W, Kirschbaum M, Dörr HG, Rascher W et al. Decreased gene expression of 11beta-hydroxysteroid dehydrogenase type 2 and 15-hydroxyprostaglandin dehydrogenase in human placenta of patients with preeclampsia. Journal of Clinical Endocrinology and Metabolism 200186 13131317.

16 Bertram C, Trowern AR, Copin N, Jackson AA \& Whorwood CB. The maternal diet during pregnancy programs altered expression of the glucocorticoid receptor and type 211 beta-hydroxysteroid dehydrogenase: potential molecular mechanisms underlying the programming of hypertension in utero. Endocrinology $2001 \mathbf{1 4 2}$ 2841-2853.

Received 28 January 2002

Accepted 31 January 2002 